творчо використовуючи накопичений досвід, що $є$ невід'ємними якостями справжнього вчителя [2, с. 104].

Метод проектів завжди орієнтований на самостійну діяльність студентів, формує вміння самостійно обирати різні рішення, шляхи отримання інформації, генерувати ідеї, гіпотези, прогнозувати їх розв'язання.

Отже, виконання студентами проектів передбачає залучення їх до виявлення та аналізу реальних практичних проблем, пов’язаних із майбутньою професійною діяльністю і використанням для цього практичної дослідницько-пошукової роботи.

Перспективи подальших досліджень убачаємо в розробленні моделі формування мовної особистості майбутніх перекладачів.

\title{
Література
}

1. Бахов I.C. Формування міжкультурної професійної компетентності у студентів-перекладачів: [монографія]/ І. С. Бахов. - К. : ДП «Вид. дім «Персонал», 2009. - 268 с 2. Бондаренко Г. Метод проектів як засіб удосконалення методичної компетентності майбутніх учителів української мови та літератури / Г. Бондаренко / Вісник Луганського національного університету імені Тараса Шевченка. - 2012. № 12. - Ч. 2 - С. 97-104. 3. Полат Е. С. Что такое проект : типология проектов/ Е. С. Полат // Открытый урок. - 2004. - № 5 - 6. - С. 10-17.

УДК 378.013-047.22

Ірина Драч

\section{ЗАСТОСУВАННЯ ПРИНЦИПУ КОМАНДНОСТІ В УМОВАХ КОМПЕТЕНТНІСНО ОРІЕНТОВАНОГО УПРАВЛІННЯ ПІДГОТОВКОЮ МАЙБУТНІХ ФАХІВЦІВ}

Драч I. I. Застосування принципу командності в умовах компетентнісно орієнтованого управління підготовкою майбутніх фахівців.

У статті охарактеризовано специфічні риси, що визначають самостійний статус компетентнісно орієнтованого управління підготовкою майбутніх фахівців у системі управлінської освітньої діяльності. Обгрунтовано використання принципу командності під час реалізації нової парадигми управління. Розкрито сутність теорії I. Адізеса щодо причини успішного та неуспішного менеджменту, у якій описано управлінські ролі, що дають змогу організації бути результативною й ефективною в короткому та довгому періоді. Зроблено висновок, що для досягнення ефективного менеджменту необхідна взаємодія у групі людей із взаємодоповнювальними стилями управління, тобто взаємодоповнювальна команда. Охарактеризовано переваги використання матричної організаційної структури, а також сукупності методів під час створення команди в умовах компетентнісно орієнтованого управління.

Ключові слова: професійна підготовка, компетентнісно орієнтоване управління, принципи педагогічного управління, взаємодоповнювальна команда.

Драч И. И. Использование принципа командности в условиях компетентностно ориентированного управления подготовкой будущих специалистов.

В статье охарактеризованы специфические черты, определяющие самостоятельный статус компетентностно ориентированного управления подготовкой будущих специалистов в системе управленческой образовательной деятельности. Обосновано использование принципа командности при реализации новой парадигмы управления. Раскрыта сущность теории И. Адизеса о причинах успешного и неуспешного менеджмента, в которой описаны управленческие роли, позволяющие 
организации быть результативной и эффективной в коротком и длинном периоде. Сделан взвод о том, что для достижения эффективного менеджмента необходимо взаимодействие в группе людей с взаимодополняющими стилями управления, то есть взаимодополняющая команда. Охарактеризованы преимущества использования матричной организационной структуры, а также совокупности методов при создании команды в условиях компетентностно ориентированного управления.

Ключевые слова: профессиональная подготовка, компетентностно ориентированное управление, принципы педагогического управления, взаимодополняющаяся команда.

Drach I. I. Using the principle of command in the conditions of competence-based management training of future specialists.

The article described the specific features that define the independent status of the competence-based management training of future professionals in the management of educational activities. The use of principles of team in the implementation of a new management paradigm is justified. The essence of the theory I. Adizes about the reasons for the successful and unsuccessful management, which describes the role of management to enable an organization to be effective and efficient in the short and long term is disclosed. It is concluded that in order to achieve effective management must interact in a group of people with complementary management styles, that is a complementary team. The advantages of using a matrix organizational structure, as well as a set of methods when creating a team in a competence-based management are described.

Key words: training, competence based management, principles of pedagogical management, complementary team.

Шлях європейської та світової інтеграції, обраний Україною, зумовлює необхідність реформаційних процесів в освітній галузі, спрямованих на досягнення найкращих освітніх стандартів. Національна доктрина розвитку освіти [10], Національна стратегія розвитку освіти в Україні на період до 2021 р. [12], Закон України «Про вищу освіту» [7] заклали підвалини нової парадигми - орієнтацію на новий тип гуманістично-інноваційної освіти, іiї конкурентоспроможність в європейському та світовому просторах. У цих стратегічних документах визначено і нову модель управління освітою, яка має стати відкритою i демократичною, спрямованою на розвиток самостійності та самодостатності особистості, іiі творчої активності задля зміцнення демократичних основ громадянського суспільства. Така позиція потребує від сучасної освіти серйозних реформаційних кроків щодо оновлення механізмів управлінської діяльності.

Зважаючи на те, що результат сучасної професійної підготовки майбутніх фахівців визначається в термінах компетентностей та компетенцій, нами виокремлено специфічні риси, що визначають самостійний статус компетентнісно орієнтованого управління підготовкою майбутніх фахівців у системі управлінської освітньої діяльності [5]. Це:

- спрямованість на формування професійної компетентності студентів. Основною метою управлінського процесу $\epsilon$ створення умов для ефективного формування професійної компетентності магістрантів педагогіки вищої школи; цій мети має підпорядковуватися освітній процес і всі управлінські впливи вищого навчального закладу;

- інноваційний характер. Цей вид управління пов'язаний 3 реалізацією інноваційних процесів з оптимізації професійної підготовки майбутніх викладачів; 
- особистісно зорієнтований характер. Компетентнісно орієнтоване управління дає змогу варіювати структуру, зміст і темпи засвоєння освітньої програми, що забезпечує побудову індивідуальних освітніх траєкторій студентів;

- комплексність реалізації у структурі системи менеджменту якості освіти. Цей вид управління охоплює всі основні напрями організації професійної підготовки, вбираючи в себе управління: якістю змісту, якістю технологічного супроводу і якістю результату освітнього процесу [13].

Реалізація компетентнісно орієнтованого управління грунтується на принципах національно-державного характеру освіти; соціокультурної зумовленості; системності; науковості; цілеспрямованості; інформаційної достатності; зворотного зв'язку; демократизації; гуманізації; єдності централізації і децентралізації; адаптивності; маркетингу; психологізації; відкритості; динамічності; колегіальності; поєднання управління функціонуванням i розвитком системи управління; прогнозованості; командності [4].

Актуальними напрямами пошуку нових педагогічних, філософських та управлінських ідей, які можуть слугувати підгрунтям сучасної теорії управління освітою, $\epsilon$ визначення пріоритетних цінностей, цілей і норм процесу управління.

Серед праць, у яких містяться найбільш значущі результати 3 проблеми виокремлення принципів педагогічного управління, відзначимо роботи В. Бондаря [2], О. Галуса [3], Г. Сльникової [6], В. Кременя, С. Пазиніча, О. Пономарьова [8], В. Маслова [9], В. Олійника [11]. Водночас зауважимо, що проблему визначення та систематизації принципів управління передчасно вважати розв'язаною. Не знайшла належного відображення в сучасних наукових джерелах, зокрема, проблема застосування принципу командності в управлінні підготовкою майбутніх фахівців.

Метою статті є розкриття особливостей застосування принципу командності під час реалізації компетентнісно орієнтованого управління підготовкою майбутніх фахівців.

Застосування принципу командності при здійсненні управлінської діяльності спрямовано на реалізацію нової парадигми управління, яка характеризується плинністю, делегуванням влади та співробітництвом.

Під командою будемо розуміти спеціально підібрану групу людей для об'єднання їхніх зусиль, які працюють на досягнення спільної мети. Характерними ознаками команди $€$ : наявність спільної мети; інтенсивне співробітництво; визначені статусно-рольові відносини; лідерство (формальне чи неформальне); згуртованість колективу; відпрацьовані комунікативні зв'язки; групові норми поведінки, усталені традиції; схожість основних життєвих цінностей, установок; специфічні методи вироблення колективних рішень; сприятлива соціально-психологічна атмосфера.

Створення команди під час управління професійною підготовкою майбутніх фахівців означає побудову управлінської діяльності на засадах взаємної довіри та поваги, сприяє мінімізації конфліктів у вищому навчальному закладі, забезпечує ефективну спільну працю для досягнення мети, за якої підсумковий ефект спільної діяльності окремих людей більший від того, що кожний 3 них міг би зробити самостійно.

Серед праць 3 проблем створення команд особливо важливою, на нашу думку, $\epsilon$ праця «Ідеальний керівник: чому ви не можете стати ним, i що робити 3 цього приводу» провідного світового експерта з покращення діяльності бізнесу та урядових організацій I. Адізеса [1], у якій проаналізовано причини успішного та неуспішного менеджменту, описано управлінські ролі, які дають змогу організації бути результативною й ефективною в короткому та довгому періоді. 
Сучасні теорії менеджменту базуються на американській культурі індивідуалізму, і тому весь процес управління, тобто всі завдання, покладено на одну особу - керівника або лідера. Основним положенням, яке вирізняє теорію І. Адізеса, $є$ те, що, на думку автора, ідеального лідера, менеджера чи керівника - ідеального в тому сенсі, що він самостійно може забезпечити всі ролі, необхідні для коротко- і довгострокової ефективності та результативності організації, - просто не існує.

I. Адізес формулює такі основні припущення:

- добре керована організація повинна бути продуктивною в короткому та довгому періодах;

- для того, щоб організація була добре керованою, ву ній повинні виконуватися чотири ролі: виробництво (Р) адміністрування (А), підприємливість (Е), інтегрування частин організації (I). Ці чотири ролі є вітамінами. Якщо одного бракує, настає хвороба;

- ніхто не може виконувати всі чотири ролі одночасно. Нормальна людина здатна на одну або дві, рідко на три ролі. Тому ідеального керівника, який здатний виконувати всі ролі одночасно, не існує та існувати не може.

Перша роль - продукування (Р), тобто виробництво. Мета виробника задовольнити потреби клієнта. Здійснюється в короткому періоді.

Друга роль - адміністрування (А). Адміністратор працює над тим, щоб організаційні процеси були систематизованими: компанія робила правильні речі, у правильному порядку з правильною інтенсивінстю. Роль адміністратора - забезпечити ефективність у короткому періоді.

Третя роль - підприємця (Е). Поєднує креативність із бажанням ризикувати. Якщо в організації ця роль виконується добре, то в ній завжди будуть послуги та/або продукти, потрібні майбутнім клієнтам. Здійснюється в довгому періоді.

Четвертая роль - інтегрування (I). Означає побудову клімату, комунікацій та системи цінностей, які б мотивували людей в організації працювати разом, забезпечуючи ефективність у довгому періоді.

Стилі менеджменту визначаються домінантними та менш розвинутими ролями.

Наприклад, якщо у менеджера сильно розвинута виробнича (Р) роль, а інші лише на відповідному рівні, то код цього стилю буде Раеі. Інший менеджер буде сильний в організації- код pAei, у відчутті майбутніх тенденцій- paEi, у комунікації та мотивуванні - paeI.

Якщо виконується лише одна роль (наприклад, Р---, -A--, --E-, ---I), то виникає відповідний стиль неефективного управління:

P---: самотній рейнджер. Ідеальний виконавець. Дуже багато працює, хоче все робити сам. Зосереджений на тому, щзо робити, а не хто і чому. Не любить мати справу із невідомістю, альтернативою або невизначеністю.

А--: бюрократ. Дотримується всіх правил, часто надмірно. Зосереджений на тому, як робити. Все документує. Набирає людей, схожих на себе - безініціативних виконавців. Не ризикує.

Е-: підпалювач. Має дуже велику потребу створити щось нове, що часто означає знищити наявне. Всі зусилля скеровані на інновації, постійні зміни. Ризикує. Що і як робити - неважливо, його хвилює скоріше чому б нi? Ахіллесова п'ята - деталі.

I: суперпослідовник: Намагається зрозуміти, який план буде прийнятним для максимальної кількості людей. Має добру «політичну» інтуїцію.

Для досягнення ефективного менеджменту необхідна взаємодія у групі людей із взаємодоповнювальними стилями управління, тобто взаємодоповнювальна команда. У команді потрібні люди, у кого розвинута хоча б одна з чотирьох ролей, відмінна від 
ролей інших членів команди, а інші ролі - на достатньому рівні. Тобто для створення команди необхідно підбирати людей 3 різними стилями управління. Очолювати команду має визнаний лідер, якому необхідно мати добре розвинутими дві або більше ролей: обов'язково інтеграцію (I), а інші не нижче мінімально допустимого рівня.

На нашу думку, виявленню лідерів, а також здатності членів колективу до виконання необхідних ролей у команді сприяє матрична організаційна структура, яка поєднує лінійно-функціональну структуру з проектним управлінням. У межах цієї організаційної структури створюються проектні команди, її характерною ознакою $є$ командна система відповідальності та розподілу обов'язків.

Проведений аналіз характеристик матричної організаційної структури, представлених у науковій літературі, дав нам змогу зробити узагальнення, які обгрунтовують перспективність їі використання під час створення команди у вищому навчальному закладі, а саме:

- для матричної організаційної структури управління характерні суб'єктсуб'єктні відносини між керуючою та керованою підсистемами, керівниками та підлеглими, педагогами та студентами;

- матрична організація управління успішно справляється 3 управлінням гнучкими комплексними освітніми процесами, а також розвитком процесів організаційних змін;

- використання матричної структури обумовлює ефективність управління, заснованого на принципах партисипатизма - своєрідної альтернативи авторитарності, директивності, примусу, що забезпечує підвищення якості управління, детерміноване, по-перше, поглибленням і розширенням взаємодії суб'єктів освіти, по-друге, підвищенням комфортності освітнього процесу в цілому, по-третє, формуванням необхідних особистісних якостей учасників взаємодії.

Отже, саме матрична організаційна структура уможливлює випробування членів колективу в різних ролях i, як підсумок, усвідомлення ними власної здатності до виконання певних ролей у команді, розуміння необхідності залучення людей 3 різними стилями управління для ефективної роботи. Перевагами цієї структури управління є також ефективна координація робіт, яка дає змогу долати роз'єднаність між структурними підрозділами; сприяння саморозвитку та самореалізації учасників процесу управління, оскільки вони $є$ вільними у прийнятті локальних управлінських рішень; зближення внутрішніх потреб учасників управлінських впливів 3 цілями організації, що сприяє зміцненню «командного духу».

Важливими методами компетентнісно орієнтованого управління, спрямованими на створення команди та забезпечення взаємодії між ії членами, вважаємо методи дискусії, мозкового штурму, соціально-психологічні методи управління.

Метод дискусії передбачає участь широкого кола учасників, виявлення різних думок, інтересів та взаємоузгодження цих думок. Дискусії спрямовуються на спільний пошук оптимальних шляхів вирішення проблем. При цьому проведення дискусій має спиратися на вільний виклад учасниками своїх поглядів, зіставлення різних підходів, публічне обговорення переваг і недоліків дискусійної проблеми. Так, у ході впровадження моделі компетентнісно орієнтованого управління організовувалися дискусії з проблем та перспектив підготовки майбутніх фахівців, критеріїв ефективності управління формуванням професійної компетентності студентів, напрямів удосконалення організації навчального процесу. Таким чином, у ході дискусії відпрацювувалися всі ролі (Р, А, Е, I), необхідні для ефективного менеджменту.

Метод мозкового штурму полягає у виключенні під час обговорення тієї чи тієї 
проблеми будь-якої критики ідей, що висувалися. Цей метод передбачає, що процеси генерування нових ідей та їх аналітичної оцінки розподілені в часі та просторі й виконуються двома групами експертів. Вихідним пунктом проведення мозкового штурму є припущення про те, що чим більше ідей і чим вони різноманітніші за якістю, тим більше шансів, що серед них опиняться необхідні, кращі ідеї. Важливе завдання організаторів мозкового штурму полягає у створенні умов для колективної діяльності 3 генерації нових ідей. Обговорювана проблема має бути чітко сформульована, а будь-яка ідея розглянута і не може бути оголошена хибною, навіть при іiі майже очевидній безперспективності. Цей метод, який стимулював виконання ролі Е, достатньо широко використовувався на всіх етапах вупровадження моделі компетентнісноорієнтованого управління 3 огляду на відсутність розробленої методології та практичних напрацювань $з$ цієї проблеми.

Використання соціально-психологічних методів під час здійснення компетентнісно орієнтованого управління професійною підготовкою магістрантів педагогіки вищої школи було спрямовано на виконання ролі I та уможливлювало створення надійної системи соціального захисту працівників ВНЗ; позитивного морально-психологічного клімату в колективі, сприятливого для розв'язання поставлених завдань; надання можливості розвитку і реалізації особистих здібностей працівників.

Серед соціально-психологічних методів управління використовувалися такі: орієнтація колективу на досягнення спільної мети, мотивація особистісної та колективної творчої діяльності, попередження конфліктів у колективі.

Отже, дотримання принципу командності під час здійснення компетентнісно орієнтованого управління забезпечувало ефективну спільну працю для досягнення визначеної мети. При формуванні команди увага зверталася на наступні аспекти: спільна мета мала тісно узгоджуватися 3 власними потребами, інтересами членів команди; вона повинна була не лише усвідомлюватися членами команди, а й прийматися на емоційному рівні; командна діяльність передбачала активність та особисту відповідальність кожного за результат роботи команди; робота у команді грунтувалася на довірі членів команди один одному.

Використання матричної організаційної структури, а також проаналізованих методів при здійсненні компетентнісно орієнтованого управління професійною підготовкою магістрантів педагогіки вищої школи слугувало формуванню партнерських стосунків у колективі, згуртованості та взаємопідтримці працівників, створенню команди однодумців.

Перспективою подальших досліджень уважаємо розроблення інструментарію для оцінювання здатності особистості до основних управлінських функцій, а також рекомендацій для керівників щодо створення взаємодоповнювальної команди для ефективного управління освітніми закладами.

\section{Література}

1. Адізес I. Ідеальний керівник: чому ви не можете стати ним, і що робити 3 цього приводу / І. Адізес. - К. : Києво-Могилянська академія, 2006. - 266 с. 2. Бондарь В. И. Повышение эффективности подготовки директора школы к управлению процессом обучения : дис. ... д-ра пед. наук : 13.00 .01 / В. И. Бондарь.К., 1986. - 343 с. 3. Галус О. М. Педагогічне управління адаптацією майбутніх учителів у системі ступеневої освіти : дис. ... д-ра пед. наук : 13.00 .06 / О. М. Галус. К., 2008. - 407 с. 4. Драч I. I. Принципи управління професійною підготовкою майбутніх фахівців в умовах інформаційного суспільства / I. I. Драч// Педагогіка і психологія творчої особистості у вищій і загальноосвітній школах : зб. наук. пр./ 
редкол. : Т. І. Сущенко (гол. ред.) [та ін.]. - Запоріжжя, 2012. - Вип. 79 (26). - С. $137-$ 144. 5. Драч I. I. Теоретичні і методичні засади управління формуванням професійної компетентності магістрантів педагогіки вищої школи : дис. ... д-ра пед. наук : 13.00 .06 / I. І. Драч. - К., 2008. - 485 с. б. Сльникова Г. В. Наукові основи розвитку управління загальною середньою освітою в регіоні : дис. ... д-ра пед. наук : 13.00.01/ Г. В. Сльникова. - Луганськ, 2005. - 446 с. 7. Закон України «Про вищу освіту» [Електронний ресурс]. - Режим доступу: http://zakon.rada.gov.ua 8. Кремень В. Г. Філософія управління : підруч. для студ. вищ. навч. закладів / В. Г. Кремень, С. М. Пазиніч, О. С. Пономарьов. - К. : Знання України, 2007. - 360 с. 9. Маслов В. І. Наукові основи та функції процесу управління загальноосвітніми навчальними закладами : навч. посіб. / В. І. Маслов. - Тернопіль: Астон, 2007. - 150 с. 10. Національна доктрина розвитку освіти // Освіта України. - 2002. - № 33. - С. 4-6. 11. Олійник В. В. Наукові основи управління підвищення кваліфікації педагогічних працівників профтехосвіти : [монографія] / В. В. Олійник. - К. : Міленіум, 2003. 594 с. 12. Указ Президента України від 25 червня 2013 р. № 344/2013 «Про Національну стратегію розвитку освіти в Україні на період до 2021 р.» [Електронний pecypc].- Режим доступу: http://www.president.gov.ua/ru/documents/15828.html 13. Drach I. Methodology for managing a professional competence formation of future teachers in higher education / I. Drach // Europian Applied Sciences, Stuttgart, Germany. 2012. - № 1. - P. 138-140.

УДК 378. 147: 811. 111

Світлана Дуброва

\section{ПРОФЕСІЙНА ПІДГОТОВКА МАЙБУТНІХ УЧИТЕЛІВ ІНОЗЕМНИХ МОВ ДО ФОРМУВАННЯ КОМУНІКАТИВНОЇ КОМПЕТЕНЦЇ̈ УЧНІВ ОСНОВНОЇ ШКОЛИ: ПРОГРАМА, МЕТОДИКА ТА РЕЗУЛЬТАТИ ЕКСПЕРИМЕНТАЛЬНОГО ДОСЛІДЖЕННЯ}

Дуброва С. В. Професійна підготовка майбутніх учителів іноземних мов до формування комунікативної компетенції учнів основної школи: програма, методика та результати експериментального дослідження.

У статті висвітлено мету, суть, програму та методику експериментального дослідження, представлено його результати - динаміку та рівні розвитку когнітивноопераційного й оцінно-результативного компонентів готовності майбутніх учителів іноземних мов до формування комунікативної компетенції учнів основної школи на різних етапах експериментального навчання.

Ключові слова: програма і методика експериментального дослідження, динаміка рівнів готовності, професійна підготовка майбутніх учителів іноземних мов.

Дуброва С. В. Профессиональная подготовка будущих учителей иностранных языков к формированию коммуникативной компетенции учащихся основной школы: программа, методика и результаты экспериментального исследования.

В статье раскрыта цель, суть, программа и методика экспериментального исследования, представлены его результаты - динамика и уровни развития когнитивно-операционного и оценочно-результативного компонентов готовности будущих учителей иностранных языков к формированию коммуникативной компетенции учащихся основной школы на разных этапах экспериментального обучения.

Ключевые слова: программа и методика экспериментального исследования, 